\title{
Experimental investigation on light weight cellular concrete using recycled glass and plastic waste
}

\author{
Sidhardhan S. and Sagaya Albert A.* \\ Department of Civil Engineering, Government College of Engineering, Tirunelveli, Tamilnadu, India-627007 \\ Received: 20/04/2020, Accepted: 23/10/2020, Available online: 02/11/2020 \\ *to whom all correspondence should be addressed: e-mail: sandiv1025@gmail.com \\ https://doi.org/10.30955/gnj.003332
}

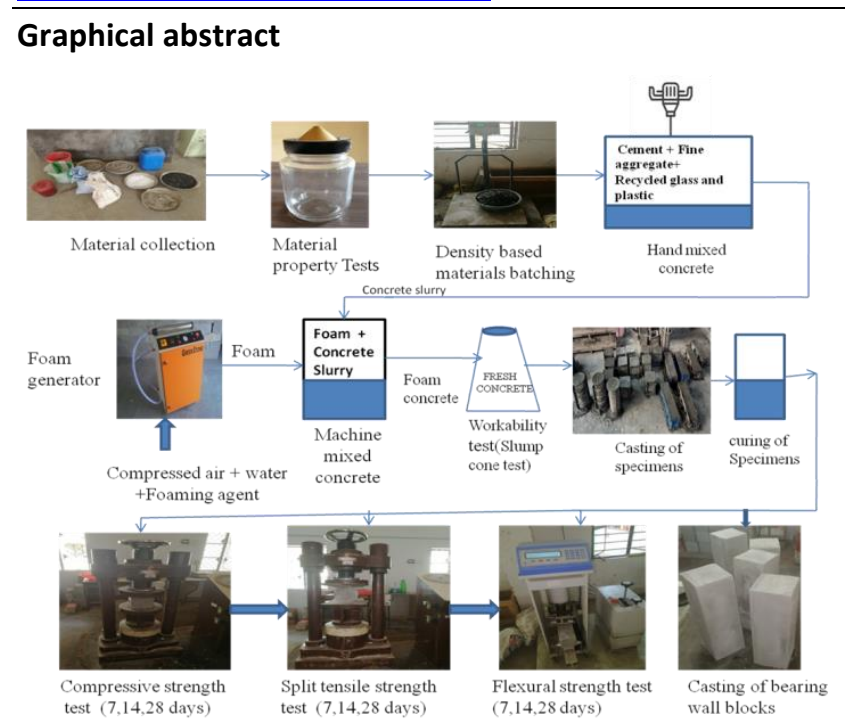

Abstract

Cellular Lightweight Concrete (CLC) also known as Foamed concrete is one of the most significant type of concrete used for construction purposes due to its various advantages and usages over traditionally produced concrete. The rapid urbanization has led to the enormous increase in wastes being disposed of. This paper aims at identifying the possibility of using recycled materials such as crushed glass and plastic wastes in foam concrete as substitute filler material for fine river sand. A protein based foaming agent was adopt for this study. The workability and strength of different mixes using powdered glass and plastic wastes were investigated. In this research study foam concrete blocks were prepared according to the designed proportions to attain the maximum density of $1900 \mathrm{~kg} / \mathrm{m}^{3} . \mathrm{In}$ this project, the mixing of recycled glass wastes $5 \%, 10 \%, 15 \%$ and recycled plastic wastes $1 \%, 3 \%$ \& $5 \%$ were added as a filler in foam concrete. The 7, 14 and 28days compressive strength, flexural strength, split tensile strength of each batch of concrete were studied and compared with conventional foam concrete. The study showed that the incorporation of recycled glass and plastic waste in conventional foam concrete is effective and it will be useful for load bearing wall applications.

Keywords: Cellular light weight concrete, protein foaming agent, strength, glass waste, plastic waste, workability.

\section{Introduction}

Foam concrete is a type of porous concrete. According to its feature and uses it is similar to aerated concrete. The synonyms are aerated concrete, lightweight concrete or porous concrete. The term foam concrete is containing no coarse aggregates only sand, cement, water and stable foam to perform the concrete. This action incorporates small, enclosed air bubbles within the mortar there by making the concrete lighter. Basically, there are two method of producing foamed concrete such as pre-foam method and inline method. In Inline method, the base mix of cement and sand is added to a unit. In this unit, the mix is blended with foam thoroughly. The process of mixing is carried out with proper control. This will help in mixing of larger quantities. The inline method can be divided into wet method and dry method. In Pre-foam method, the readymix truck brings the base material to the site. Through the other end of the truck, the pre-formed foam is injected into the truck, while the mixer is rotating. Therefore, small quantities of foam concrete can be produced for small works, like for grouting or trench fill works. Inline method is adopted in this study for the production of foam concrete since the study was carried out in laboratory with proper control. A foamed concrete is described as having an air content of more than $25 \%$ which distinguish it from highly air entrained materials. Foamed concrete may have density from as low $500 \mathrm{~kg} / \mathrm{m}^{3}$ to $1600 \mathrm{~kg} / \mathrm{m}^{3}$ and strength from less than $1 \mathrm{~N} / \mathrm{mm}^{2}$ to $25 \mathrm{~N} / \mathrm{mm}^{2}$ (Kavitha, 2018). The strength of foamed concrete is affected by the cement content of the mix, the Water/cement ratio, the proportion of cement to sand and the properties of the sand. High Compressive strength is generally achieved by using high cement content, a low water/cement Ratio and a sand. The rapid urbanization and industrialization all over the India have resulted in large deposition of waste polymer materials and waste glass materials. Accumulation of unmanageable plastic and glass waste from household and commercial is one of the serious environmental problems for many cities in India. These wastes still have not been widely utilized for years. Most of these wastages such as drinking plastic 
water bottles, tonic plastic bottles \& glass bottles, Alcohol bottles are disposed in uncontrolled waste pits. To overcome this environmental issue, waste recycling into building and construction materials would be one of several appropriate solutions not only to the environmental problems, but also to the reduction of building material costs.

The concepts, classification, properties, mix proportioning of foam concrete have been investigated by many previous researches (Paul J. Tikalsky et al. (2003); Kunhanandan et al. (2009); Ramamurthy et al. (2009); Fahrizal Zulkarnain et al. (2011), Siong kang lim et al. (2014); Mugahed Amran et al. (2015); Vikram Kathe et al. (2015); Lina et al. (2019); David Falliano et al. (2017); Qusim S Khan et al. (2018) and Raj et al. (2019). The freeze-thaw and durability of cellular concrete were discussed in detail (Paul J. Tikalsky et al. (2003). The air void structure of foam concrete by identifying few parameters like volume, size \& spacing of air void were discussed in details by (Kunhanandan et al. (2009) The classification of foamed concrete based on constituent materials, mix proportioning, production methods, fresh and hardened properties is discussed by (Ramamurthy et al. (2009). Fahrizal Zulkarnain et al. (2011) proposed a methodology to design the rational mix proportion for foam concrete. In their paper the $10 \%$ of silica fume was added to the foam concrete as replacement of cement. The silica fume is used to increase the compressive strength. The results revealed that replacing high proportions of cement with silica fume does not significantly affect the long-term compressive strength of foam concrete. Jani Y (2014) in their paper discussed the waste glass in the production of cement and concrete".

Mugahed Amran et al. (2015) in their paper discussed about the foamed concrete constituents, fabrication techniques and properties of foamed concrete. Lina et al. (2019) in their paper discussed about the main aspect that influence the application of cellular concrete like raw materials, production methods and expected properties based on density. Qusim S Khan et al. (2018) focused on their study to use the recycled glass powder in foam concrete. M. Iqbal Malik et al. (2013) in their paper studied the concrete involving use of waste glass as partial replacement of fine aggregate. Rahman et al. (2018) studied the behaviour of light weight concrete using rice husk ash and glass powder. Elango et al. (2018) studied the conventional concrete by replacing plastic waste as a fine aggregate" Raj (2019), in their study discussed the physical and functional characteristics of foam concrete.

Saikia and Brito (2012) presented a review on use of recycling plastic waste as aggregate in cement mortar and also in concrete productions. They discussed briefly about the types of plastics and types of methods used to prepare plastic aggregate, the properties of plastic aggregates and the various fresh and hardened concrete properties of cement mortar and concrete in presence of plastic aggregate, the practical implications of the use of plastic waste in concrete production and future research needs.

Yang et al. (2015) studied the behavior of self-compacting light weight concrete (SCLC) incorporated with modified polypropylene plastic particles as a replacement for sand. They concluded that the compressive strength, splitting tensile strength and flexural tensile strength are increased with the replacement level up to $15 \%$. A microscopic study on the plastic-paste interface was performed.

Chandni and Anand (2016) studies the utilization of recycled waste filler in foam concrete. The experimental results show that the incorporation of recycled waste is found to be effective to produce foam concrete of strength that will permit its use of bearing wall applications. Also, they concluded that the use of PCE based superplasticizer was observed to be effective in increasing the strength of foam concrete. They also concluded that low specific gravity fillers need more water to solids ratio for producing workable foam concrete mixes.

Vikram Kathe et al. (2015) in their paper studied the behaviour of conventional concrete by using plastic waste. The authors replace the fine aggregate by plastic waste such as Polyvinyl Chloride (PVC), Polypropylene Polyetheyene. The results show that natural sand can be replaced with the plastic waste by $10 \%$ to $20 \%$ to achieve green concrete. The sand can also replace up to $30 \%$ in the members of building which do not carry high load.

Siong kang lim et al. (2014) conducts a systematic study to ascertain the influence of filler type like sand and flyash. The author studied the particle size of sand on the properties of moist curved foam concrete. The results show that the reduction in particle size of sand caused an improvement in strength of foam concrete and the flow behaviour mainly depends on the foam volume. A.K.M.L Rahman et al. (2018) studied the behaviour of light weight concrete using rice husk ash and glass powder. The result revealed that, the similar compressive strength comes out from the composition $40 \%$ red clay. The $40 \%$ rice husk with $20 \%$ glass powder in lightweight aggregate compared to the normal aggregate. The use of glass powder shows similar compressive strength but significantly reduce the dead load density. Kennouche salim et al. (2019) in their study, the plaster was reinforced by fiber from waste plastic and powder glass. By adding $1 \%$ and $2 \%$ of plastic fiber and $5 \%$ and $10 \%$ of glass powder to reference specimen. The results show that increasing of flexural strength of the beams content of $2 \%$ of plastic fiber compared to the $1 \%$ of plastic fiber. The decreasing of flexural strength observed for the beams content of ( $2 \%$ of plastic fiber $+10 \%$ of glass powder) and ( $1 \%$ of plastic fiber $+10 \%$ glass powder) relative to $(2 \%$ of plastic fiber $+5 \%$ glass powder) and ( $1 \%$ of plastic fiber $+5 \%$ of glass powder).

Bulk volume of glass and plastic wastes are generated in both commercial and household activities and from the literature review, it is clear that, the use of glass and plastic waste as a substitution for making concrete. Also, the mechanical strength like compressive strength, tensile as well as flexural strength of such concrete was found to be increased when compared to conventional concrete. Studies shows that the increase in the percentage of substitution subsequently increases the strength up to certain limit. Research attempts have been made to determine the feasibility of using these recycled wastes in 
conventional concrete but not in foam concrete. Some limited studies are only available by using some types of waste materials in foam concrete. However, combination of recycled plastic and recycled glass waste in foam concrete has not been investigated. These waste materials (recycled plastic scrap and recycled glass powder) have been considered as the potential replacement for fine aggregates in foam concrete. Hence an attempt was made in this study to examine the mechanical strength such as compressive, split and flexural strength of foam concrete using the combination of recycled plastic scrap and recycled glass powder waste. The primary objective of this study is to develop a sustainable product using recyclable waste materials thereby attempting to partially solve the problems caused by the disposal of such waste. So, this study focused on using of these waste material in foam as a sand substitution material and check the strength characteristics.

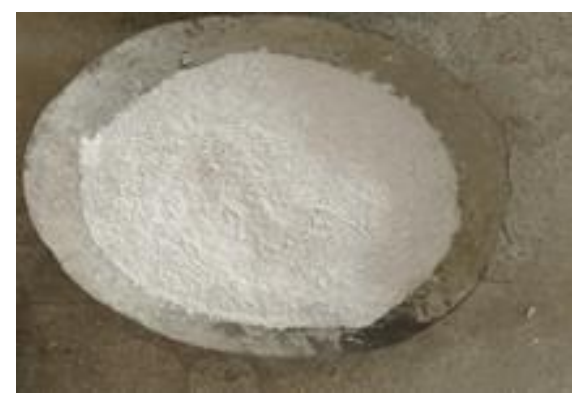

Figure 1. Recycled glass powder

\section{Materials}

\subsection{Binder}

Locally available 53 Grade Ordinary Portland Cement of specific gravity 3.13 , conforming to IS $12269: 1987$ was used.

\subsection{Fine aggregate}

Fine aggregate retained on $600 \mu \mathrm{m}$ sieve, conforming to Zone II as per IS 383-1970. The river sand passing through the $4.75 \mathrm{~mm}$ sieve used as fine aggregate in the present study. The river sand is free from impurities.

\subsection{Filler (recycled glass and plastic waste)}

Two types of recycled wastes in the powdered form were used in the study. Recycled glass powder and recycled plastic scrap are shown in Figures 1 and 2 respectively.

(a) Recycled glass powder - crushed waste soda-lime glass (of window panels and bottles), of particle size finer than $90 \mu \mathrm{m}$ and specific gravity 2.36 .

(b) Recycled thermoplastic scrap - derived from waste PET plastic bottles \& tonic bottles (after useful life and damaged) fineness modulus 2.8 and specific gravity 0.9 )

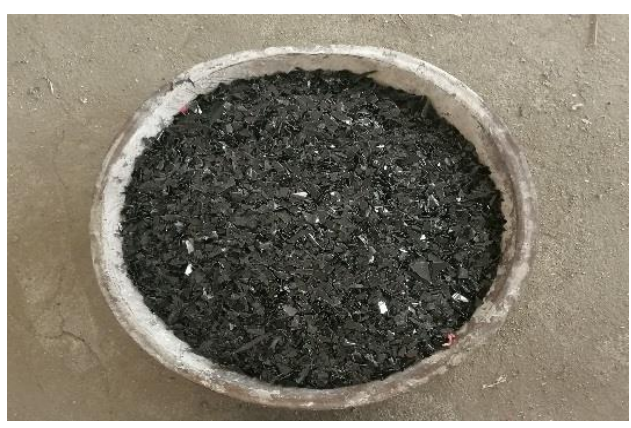

Figure 2. Recycled plastic scrap

\subsection{Foaming agents}

The foam was generated by using a foam generator by diluting the foaming agent with water and then aerating to create the foam. A vegetable protein-based liquid foaming agent of specific gravity 1.2 and having a $\mathrm{pH}$ value of 7.5 was used in this study. D.K Panser et al. (2013) compared the properties of foamed concrete by using synthetic \&protein based foaming agent. Chaosun et al. (2018) studied the behaviour of foam concrete by using synthetic surfactants, plant surfactants and animal glue/blood based surfactants. The foam generation pressure controls the mixing of air with foaming liquid and hence the foam density varies with foam generation pressure. For foam concrete, ASTM C 796 specifies the foam unit weight to be in the range of 35 to $70 \mathrm{~kg} / \mathrm{m}^{3}$. For evaluating the relative characteristics of foam produced with the foaming agent, a series of trials were carried out with two surfactant concentrations (foaming agent to water ratio), viz., 1:40 and 1:35; and aeration pressure ranging from $150 \mathrm{KPa}$ to $350 \mathrm{KPa}$. A stable foam density $40 \mathrm{~kg} / \mathrm{m}^{3}$ was obtained with a dilution of 1:35 and aeration pressure of 230KPa (using the laboratory foam generator).

\section{Methodology}

The initial properties like specific gravity, Water absorption $\&$ Fineness modulus of the cement, Fine aggregate, Coarse aggregate have been tested. The cement was tested as per the procedure given in Indian Standards IS 4031 (1988). The Fine aggregate was tested for its physical requirements such as gradation, fineness modulus and specific gravity in accordance with IS: 2386-1963. The coarse aggregate was tested for its physical requirements such as specific gravity and fineness modulus in accordance with the IS: 2386 1963(Part -3). The design mix procedure for M25 grade of concrete was derived by using IS: 10262-2009. The mix proportions of materials required for $\mathrm{M} 25$ grade of concrete is 1:1.47:2.39 with water cement ratio of 0.45 . ASTM C 796 suggests a method of estimating foam volume necessary to make cement slurry of given water cement ratio and target density. Foam concrete was prepared by the addition of pre-formed foam (with density $40 \mathrm{~kg} / \mathrm{m}^{3}$ ) into the cement-based slurry, as per equation 1 . For a target design density $\left(D \mathrm{~kg} / \mathrm{m}^{3}\right)$ of foam concrete, at a particular water to solids ratio, the quantity of cement ( $c$ $\left.\mathrm{kg} / \mathrm{m}^{3}\right)$ and filler $\left(\mathrm{kg} / \mathrm{m}^{3}\right)$ was obtained by varying the foam volume. Initially, cement and filler were weighed and dry mixed in a mortar mixer and then water $\left(w \mathrm{~kg} / \mathrm{m}^{3}\right)$ was 
added incrementally to obtain a homogeneous mix. The required quantity of foam $\left(F \mathrm{~kg} / \mathrm{m}^{3}\right)$ was added to the wet mix and mixed until the foam was uniformly distributed throughout the mix with no physical sign on the surface.

$$
D=c+f+w+F
$$

The design mix procedure for conventional foam concrete is derived by using ASTM C796. Zulkaranin (2011) in their paper explained rational proportion for mixture of foamed concrete design. The mix proportions of materials required for foam concrete is 1:2.5(Cement: Fine aggregate) with water cement ratio 0.35 . Plastic density of foamed concrete was assumed as $1900 \mathrm{~kg} / \mathrm{m}^{3}$. The workability of the conventional foam concrete was tested by using the slump cone test. It was done by filling the mix in slump cone (height $30 \mathrm{~cm}$, bottom diameter $20 \mathrm{~cm}$, Top diameter $10 \mathrm{~cm}$ ) and raising it. The slump (Vertical settlement) measured shall be recorded in terms of millimeters of subsidence of the specimen during the test. The concrete cube size for $150 \mathrm{~mm} \times 150 \mathrm{~mm} \times 150 \mathrm{~mm}$ for compressive strength test, $150 \mathrm{~mm}$ diameter with $300 \mathrm{~mm}$ height cylinder for split tensile strength test and $100 \mathrm{~mm} \times 100 \mathrm{~mm} \times 500 \mathrm{~mm}$ size prism for flexural strength test were used for cast the concrete specimens. The compressive strength, tensile strength, flexural strength of conventional foam concrete and conventional foam concrete with different mix proportions of plastic \& glass waste were compared with the compressive, Split tensile, and flexural of conventional concrete. The compressive strengths, Split tensile strengths and flexural strengths of the test sample were determined at the ages of 7, 14 and 28 days. The test were carried out as per codal provisions IS 516:1959. Table 1 presents the properties of materials used for this study.

Table 1. Material Properties

\begin{tabular}{ccccc}
\hline S.no & Physical properties & Cement & Fine aggregate & Coarse aggregate \\
\hline 1. & Specific Gravity & 3.13 & 2.64 & 2.63 \\
\hline 2. & Fineness Modulus & - & 2.94 & 6.66 \\
\hline 3. & Water Absorption & - & $0.45 \%$ & $0.13 \%$ \\
\hline 4. & Consistency & $27 \%$ & - & - \\
\hline 5. & Setting Time & $36 \mathrm{~min}$ & - & - \\
\hline
\end{tabular}

Table 2. Proportioning of the Mortar Mixtures

\begin{tabular}{ccccccccc}
\hline Notation & Cement & Water & \multicolumn{7}{c}{ Constituents (\% by Weight) } \\
\cline { 3 - 8 } & & & Foam & Sand & Coarse aggregate & Plastic scrap & Glass powder & Total \\
\hline CC & 20.57 & 9.25 & - & 30.23 & 49.20 & - & - & 100 \\
\hline CFC & 26.04 & 8.49 & 0.36 & 65.1 & - & - & - & 100 \\
\hline CFPG-1 & 26.04 & 8.49 & 0.36 & 61.21 & - & 1.95 & 3.25 & 100 \\
\hline CFPG-2 & 26.04 & 8.49 & 0.36 & 56.66 & - & 3.25 & 9.5 & 100 \\
\hline CFPG-3 & 26.04 & 8.49 & 0.36 & 52.11 & - & 100 \\
\hline
\end{tabular}

Table 3. Workability slump cone test results

\begin{tabular}{cccc}
\hline S.no & Type of Concrete & Water Cement Ratio & Slump Value(mm) \\
\hline 1 & Conventional Concrete(CC) & 0.45 & 30 \\
\hline 2 & Foam Concrete(CLC \& all CLPG Sample) & 0.35 & 130 \\
\hline
\end{tabular}

\subsection{Test samples}

For this study, the concrete cube size of $150 \mathrm{~mm} \times 150 \mathrm{~mm}$ $\mathrm{x} 150 \mathrm{~mm}$ for compressive strength, $150 \mathrm{~mm}$ diameter with $300 \mathrm{~mm}$ height cylinder for split tensile strength, $100 \mathrm{~mm} x$ $100 \mathrm{~mm} \times 500 \mathrm{~mm}$ size prism for flexural strength specimens were used. Five different types of concrete samples are presented in table 2 . The Conventional Concrete (CC) and Conventional foam concrete (CFC) were casted as per IS codal provisions. For CFPG-1(Conventional foam concrete with plastic \&glass waste-1), the sand is replaced by $1 \%$ plastic waste and $5 \%$ glass waste, For CFPG-2, the sand was replaced by $3 \%$ plastic waste and $10 \%$ glass waste. For CFPG -3 , the sand was replaced by $5 \%$ plastic waste $15 \%$ glass waste. Totally 45 cubes, 45 cylinders, 45 prisms were cast and cured at different aging conditions.

\section{Results and discussion}

\subsection{Fresh state properties}

Slump test is the most commonly used method of measuring workability of concrete. Workability of concrete is presented in table 3 . Based on the test results, the workability of conventional concrete was optimum and the workability of foam concrete was high.

\subsection{Compression strength}

Chien chung-chen et al. (2015) conducted experiments on a conventional concrete, replacing the fine aggregate by recycled plastic of $0 \%, 10 \%, 20 \%, 30 \%, 40 \%, 50 \%$ and $100 \%$. Similarly, the trend of strength reduction has been found in previous research (Atul et al., 2018) the compressive strength results shows that addition of $1 \%$ of plastic in concrete causes about $20 \%$ reduction of strength. The results also show that the $10 \%$ replacement level decrease the $15 \%$ loss of compressive strength. The compressive strength results of the test samples at the ages of 7, 14, 28 days are presented in Table 4 . The average compressive strengths of the conventional foam concrete and conventional foam concrete mixed with plastic and glass waste were lower compressive strength than the 
compressive strength of conventional concrete. However, the average compressive strength of conventional foam concrete mixed with the plastic and glass waste indicates a trend of increasing with increasing ages. It was observed that the compressive strength increased for sample CFPG2 than sample CFPG-1. But the compressive strength decreased for sample CFPG-3 than CFPG-2. Figures 3 and 4 shows that Compressive Strength relations between CC and CFC Samples and Compressive strength relations between CFPG-1, CFPG-2 \& CFPG-3 Samples respectively.

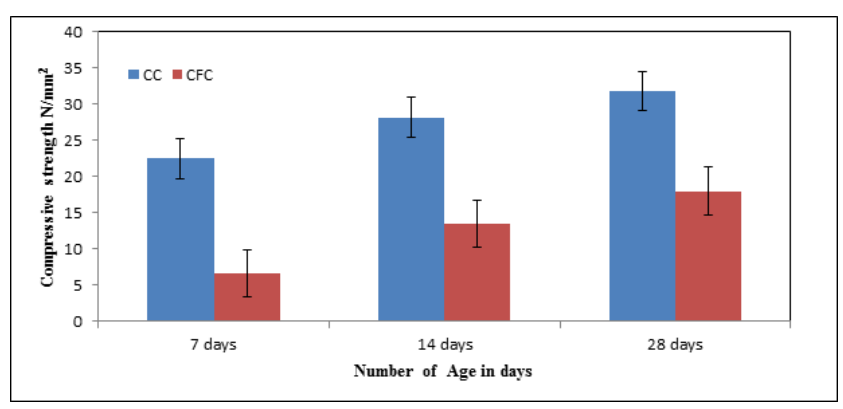

Figure 3. Compressive Strength relations between CC and CFC Samples with ages

Table 4. Compressive strengths of test sample

\begin{tabular}{|c|c|c|c|c|c|}
\hline \multirow{2}{*}{ Notation } & \multirow{2}{*}{ Cross sectional area $\left(\mathrm{mm}^{2}\right)$} & \multicolumn{3}{|c|}{ Average compressive strength (MPa) } & \multirow{2}{*}{$\begin{array}{c}\begin{array}{c}\text { Percentage of variation with CC at } 28 \\
\text { days }\end{array} \\
\end{array}$} \\
\hline & & 7-days & 14- days & 28 -days & \\
\hline $\mathrm{CC}$ & \multirow{5}{*}{22500} & 22.51 & 28.21 & 31.84 & - \\
\hline CFC & & 6.68 & 13.50 & 18.01 & $43.44 \%$ (less) \\
\hline CFPG-1 & & 6.82 & 13.64 & 18.04 & $43.35 \%$ (less) \\
\hline CFPG-2 & & 6.82 & 14.26 & 18.56 & $41.71 \%$ (less) \\
\hline CFPG-3 & & 6.80 & 13.77 & 18.28 & $42.59 \%$ (less) \\
\hline
\end{tabular}

Table 5. Tensile strength of test Sample

\begin{tabular}{|c|c|c|c|c|}
\hline \multirow{2}{*}{ Notation } & \multirow{2}{*}{ Cross sectional area $\left(\mathrm{mm}^{2}\right)$} & \multicolumn{3}{|c|}{ Average tensile strength (MPa) } \\
\hline & & 7-days & 14- days & 28 -days \\
\hline $\mathrm{CC}$ & & 1.45 & 1.86 & 2.35 \\
\hline CFC & & 1.19 & 1.55 & 1.74 \\
\hline CFPG-1 & 31415 & 1.19 & 1.47 & 1.70 \\
\hline CFPG-2 & & 1.19 & 1.60 & 1.88 \\
\hline CFPG-3 & & 1.24 & 1.60 & 1.79 \\
\hline
\end{tabular}

Table 6. Flexural strengths of the test Samples

\begin{tabular}{ccccc}
\hline \multirow{2}{*}{ Notation } & \multirow{2}{*}{ Cross sectional area $\left(\mathbf{m m}^{2}\right)$} & \multicolumn{3}{c}{ Average flexural strength (MPa) } \\
\cline { 3 - 5 } & & & 14-days & 28-days \\
\hline CC & \multirow{2}{*}{50000} & 2.38 & 2.91 & 3.53 \\
\hline CFC & & 2.96 & 3.21 \\
\hline CFPG-1 & & 2.83 & 3.07 & 3.21 \\
\hline CFPG-2 & & 2.90 & 3.10 & 3.48 \\
\hline
\end{tabular}

\subsection{Tensile test results}

Awham mohammed hameed et al. (2018) in their paper the split tensile results shows that adding $1 \%$ of PET to the reference batch gives the optimum value of spilt tensile strength with increment ratio $130 \%$.The density values clearly decreased with increasing the percentage of PET content, the decreasing ratio of density close to $14 \%$ especially at $10 \%$ of PET. The tensile strength results of the test samples at the ages of 7, 14, 28 days are presented in Table 5. The average tensile strengths of the conventional foam concrete and conventional foam concrete mixed with plastic and glass waste were lower tensile strength than the tensile strength of conventional concrete. The sample CFPG-2 have higher tensile strength value than CFPG-1 and CFPG-3. Similarly CFC and CFPG -1, CFPG-2, CFPG-3 have low tensile strength than conventional concrete. Figures 5 and 6 shows that tensile Strength relations between CC and CFC Samples and tensile strength relations between CFPG1, CFPG-2 \& CFPG-3 Samples respectively.
Tensile strength for cylinder $=(2 \times P) /(\pi \times D \times H)$

Where, P - Ultimate Load, D - Diameter of Cylinder, H Height of cylinder

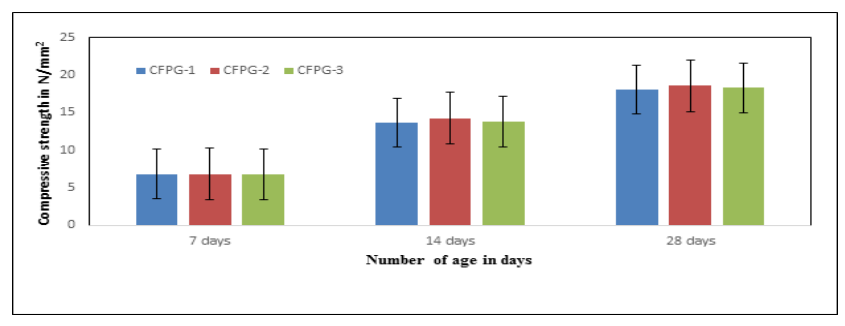

Figure 4. Compressive strength relations between CFPG-1, CFPG2 \& CFPG-3 Samples with ages 


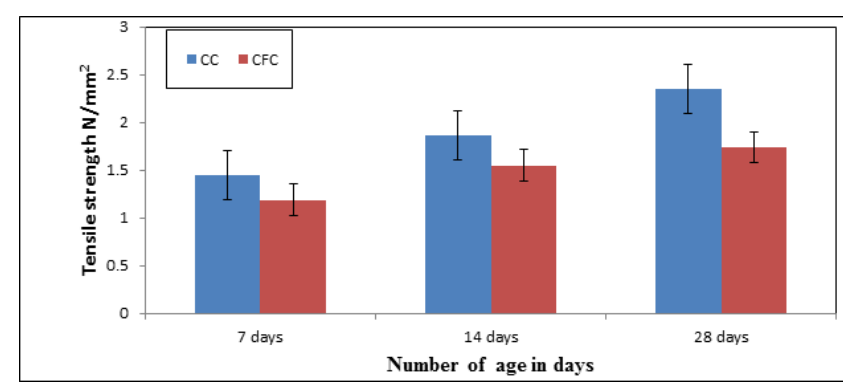

Figure 5. Tensile strength relations between CC and CFC Samples

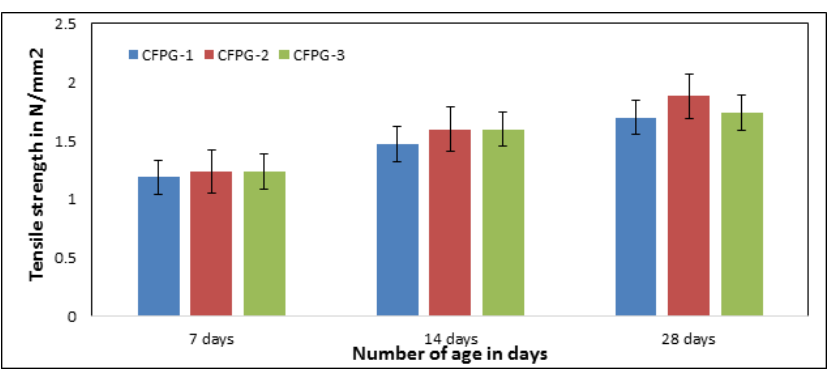

Figure 6. Tensile strength relations between CFPG-1, CFPG-2 \& CFPG-3 Samples with ages

\subsection{Flexural strength test result}

Flexural strength is a mechanical parameter for brittle material. Flexural strength also known as modulus of rupture or bend strength. It is defined as a material's ability to resist deformation under load. Hama S.M. (2019), discussed the Flexural behaviour of reinforced concrete beam incorporating waste glass powder" The flexural strength results of the test samples at the ages of 7, 14, 28 days are presented in Table. The flexural strength of conventional concrete was higher than the conventional foam concrete and conventional foam concrete with plastics and glass waste. But the sample CFPG- 2 have higher flexural strength than CFPG-1 and CFPG-3.Figures 7 and 8 shows that flexural Strength relations between CC and CFC Samples and flexural strength relations between CFPG-1, CFPG-2 \& CFPG-3 Samples respectively.

Flexural strength for Prism $=\left(3 \mathrm{FL} / 2 \mathrm{bd}^{2}\right)$

Where, $\mathrm{F}$ - Load force at the fracture point $\mathrm{L}$ - Length of the Support Span b-Width, D - Thickness

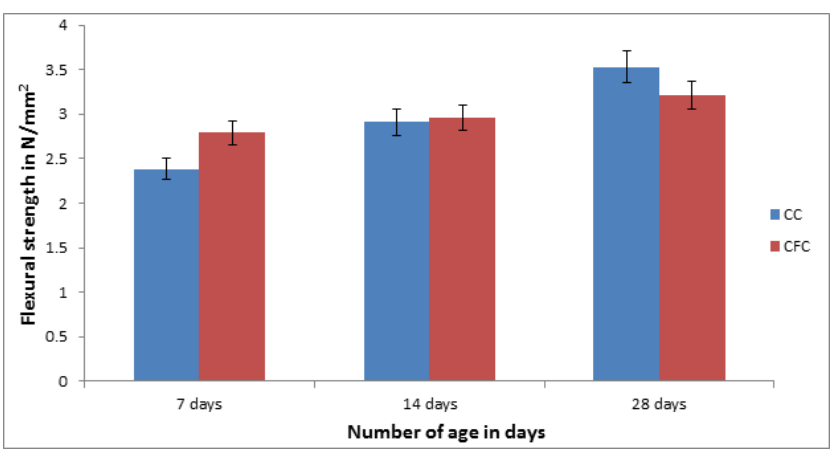

Figure 7. Flexural strength relations between $\mathrm{CC}$ and CFC Samples

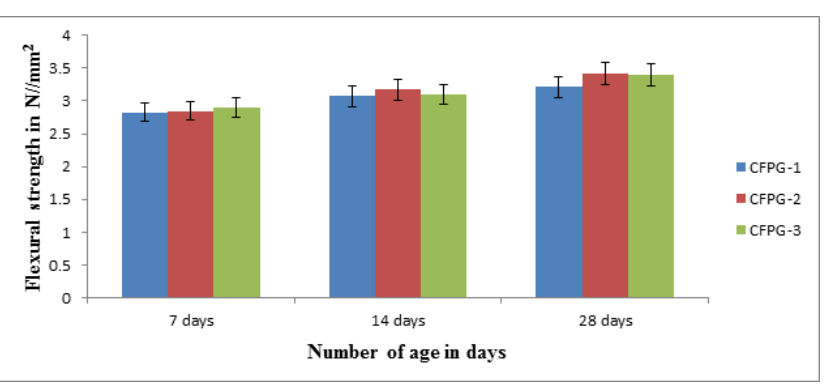

Figure 8. Flexural strength relations between CFPG-1, CFPG-2 \& CFPG-3 Samples with ages

\section{Conclusion}

This research study investigates the feasibility of the foam concrete mixed with the combination of recycled plastic and glass waste. The research has focused on the compressive strength, tensile strength, and flexural strength of the foam concrete mixed with the combination of recycled glass and plastic waste. Based on the experimental results and analytical investigations, the following conclusions are drawn:

1. The compressive strength and durability of foam concrete increases with the age. But the compressive strength of this concrete mixes (i.e. CFPG-1, CFPG-2 \& CFPG-3) was 41 to $44 \%$ lower than conventional concrete at 28 days.

2. The compressive strength of concrete mix (CFPG-2) was higher than concrete mix 1 (CFPG-1) and Concrete mix 3 (CFPG-3). The compressive strength of concrete mix (CFPG-1) was $2.9 \%$ lower than concrete mix 2 (CFPG-2). So the sample CFPG- 2 gave the better compressive strength.

3. The tensile strength and flexural strength of this concrete mixes increases with age.

4. The replacement of $3 \%$ plastic \& $10 \%$ glass as a filler in conventional foam concrete have $20 \%$ lesser tensile strength compared to the conventional concrete at 28 days. But the concrete mix (CFPG-2) gives $8 \%$ higher tensile strength than the conventional foam concrete (CFC).

5. The flexural strength of concrete mix (CFPG-2) was only $1.5 \%$ lower than the Conventional concrete. The sample CFPG-2 have higher flexural strength than sample CFPG-1 and CFPG-3.

6. So overall the Sample CFPG-2 have higher compressive strength, tensile strength and flexural strength than sample CFPG-1 and sample CFPG-3. But sample CFPG-2 have lesser compressive strength, tensile strength and flexural strength than conventional concrete (CC).

7. The starting of strength gain for foamed concrete was on higher side than that of conventional concrete and strength gain beyond 28 days was faster than conventional concrete.

8. The mixed proportion for foamed concrete used in this research report cannot be used for structural purpose, because the compressive strength is 
lower than conventional concrete. The various mix proportions in this research can be used for making of partition wall in building.

9. The use of recycled glass and plastic in conventional foam concrete reduce the consumption of fresh raw materials especially sand. It promotes the judicial and sustainable use of sand. So the combination of recycled glass and plastic waste can be used as a filler in conventional foam concrete.

\section{References}

Amran Y.H.M., Farzadnia.N. and Ali. A.A.A. (2015), Properties and applications of foamed concrete: A review, 101, Part 1, pp: 990-1005

ASTM-C796, Standard Test method for foaming agents for use in producing cellular Concrete Using Preformed Foam.

Atul R. (2012), Use Of Plastic in a concrete to improve its properties, International Journal of Advanced Engineering Research and Studies, 1, 109-111.

Chandni T.J. and Anand K.B. (2016), Utilization of recycled waste as filler in foam concrete, Journal of Building Engineering, 19, 154-160.

Cheien-Chung C., Jaffe N., Weimer M.K.W. and Polocoser A. (2015), Concrete mixture with plastic as fine aggregate replacement, 2(4).

Elango A. and Kumar A.A. (2018), Study on partial replacement of plastic waste as fine aggregate in concrete, International Journal of current Engineering and scientific research, 5.

Falliano D., Domenico D.D. and Gugliandolo G.R.E. (2018), Experimental Investigation on the compressive strength of foamed concrete: Effect of curing conditions, cement type, foaming agents, Construction and Building Materials, 165, 735-749.

Hama S.M., Mahmoud A.S. and Yassen M.M. (2019), Flexural behaviour of reinforced concrete beam incorporating waste glass powder, Structures, 20, 510-518

Hameed A.M., Abdul B., and Ahmed F. (2019), Employment the plastic waste to produce the lightweight concrete, Energy Procedia, 157, 30-38

Iqbalmalik M., Ahmad M.B.S., Tariq T. and Chowhary U. (2013), Study of concrete involving use of waste glass as partial replacement of fine aggregate, 3, 8-13.

IS: 10262-2009 Concrete Mix Proportioning Guidelines.

IS: 2386-1963(Part-3) Methods of Test for Aggregates for Concrete.

IS: 2386-1963 (Part-1) Methods of Test for Aggregates for Concrete.

IS: 4031-1988 Methods of Physical tests for hydraulic cement

Jani Y. and Hogland W. (2014), Waste glass in the production of cement and concrete: A review, Journal of Environmental Chemical Engineering, 2, 1767-1775.

Kathe V., Gangurde A. and Pawer A. (2015), Green concrete using plastic waste, Internatinal Journal of Engineering Trends and Technology, 19, 214-216.

Kavitha D. and Mallikarjunrao K.V.N. (2018), Design and analysis of foam concrete, International Journal of Engineering Trends and applications(IJETA), 5(3), 113-128

Khan Q.S., Neaz Sheiokh M., Timothy J., Robati M.M. and Allen M. (2019), Experimental Investigation on foam concrete without and with recycled glass powder: A sustainable solution for the future construction, Construction and Building Materials, 201, 369-379

Lim S.K. and Tan C.S. (2014), Strength and toughness of lightweight foamed concrete with different sand grading, KSCE Journal of Civil Engineering, 19.

Nambiar E.K.K. and Ramamurthy K. (2007), Air void characterization of foam concrete, Cement and Concrete Research, 37, 221-230.

Panesar D.K. (2013), Cellular concrete properties and effect of synthetic and protein foaming agents, Construction and Building Materials, 44, 575-584.

Rahman A.K.M.L., Barai A., Sarkar A. and Moniruzzaman M. (2018), Light weight concrete from rice husk and glass powder, Bangladesh Journal of Scientific and Industrial Research, 225-232.

Raj A., Sathyan D. and Muni K.M. (2019), Physical and functional characteristics of foam concrete: A review, Construction and Building Materials, Amritha School of Engineering, Coimbatore, Amrita Vishwa Vidyapeetham, India, 221, 787789.

Ramamurthy K., Nambair E.K.K. and Ranjani G.I.S. (2009) A classification of studies on properties of foam concrete, Cement and Concrete Composites, Building Technology and Construction Management Division, Indian Institute of Technology Madras, Chennai, 31, 388-396

Saika N., Brito J. (2012) Use of plastic waste as aggregate in cement mortar and concrete preparation: A review, Construction of Building Materials, 34, 385-401.

Salim K., Houssam A., Belaid A., Brahim H. (2019), Reinforcement of building plaster by waste plastic and glass, ICSI 2019, The $3^{\text {rd }}$ International conference in structural Integrity, 17, 170176.

Shaikh S., Bachhav S.S. and Kshirsagar D.Y. (2015), Effective utilization of waste glass in concrete, International Journal of Engineering Research and Applications, ISSN:2248-9622, 5, 1-4.

Stiti N., Ayadi A., Lerabi Y., Benhaoua F., Benzerga R., and Legendre L. (2011), Preparation and characterization of foam glass based waste, Asian Journal of Chemistry, 23, 3384-3386.

Sun C., Zhu Y., Guo J., Zhang Y. and Sun G. (2018), Effects of foaming agent type on the workability, drying shrinkage, frost resistance and pore distribution of foamed concrete, Construction and Building Materials, 86, 883-839.

Yang S., Yue X., Liu X. and Tong Y. (2015), Properties of Selfcompacting lightweight concrete containing recycled plastic particles, Construction of Building Materials, 84, 444-453.

Zulkaranin F. and Ramli M. (2011), Rational proportion for mixture of foamed concrete design, Jurnal Teknologi, 55. 10.11113/jt.v55.73. 